\title{
Land for Welfare in China
}

\author{
Meina Cai \\ Department of Political Science \\ University of Connecticut \\ 365 Fairfield Way, Unit 1024 \\ Storrs, CT 06269-1024, USA \\ E-mail:meina.cai@uconn.edu \\ Phone: 1-860-486-3352 \\ Fax: 1-860-486-3347
}




\title{
Land for Welfare in China
}

\begin{abstract}
Drawing on firsthand observations, Party and government documents, and survey data, this study examines the causes and processes of the land for welfare policy in China. The implementation of the land for welfare program cannot be understood in isolation from the profound urban-rural gap in the land property rights regime and social welfare provision in China. The dual land tenure system allows local officials to generate revenue by expropriating rural land, which, to rural households, functions as a social insurance as well as an income-generating property. In the process of land requisition, land-losing villagers are provided with social welfare benefits to compensate for their loss of their land's insurance function. Such provision, however, is not developed out of the local governments' benign intention, but their strategic reaction to the central government's development program that combines rural social welfare provision with a land rewarding system, which provides an opportunity for local officials to gain more land, a valuable asset for local governments. The provision of social welfare benefits is selective: affected rural households are provided with welfare benefits that are less costly to the local government, typically in the form of a pension insurance.
\end{abstract}

Keywords: land quotas; land-taking compensation; social welfare provision; urban-rural divide; China

\section{Introduction}

China has impressed the world with its fast-growing economy and rapid urbanization over the past 30 years. China's urban population surpassed its rural population for the first time in the country's history at the end of 2011, during which time China had a urban population of 691 million, or $51 \%$ of the total population, rising from $18 \%$ in 1978 (National Bureau of Statistics of China 2012). This process of urbanization is far from complete yet. The Chinese government is pushing ahead with an incredible mission of moving another 250 million rural residents into the urban areas over the next dozen years (Johnson 2013). One of the associated problems with rapid urbanization is the growing number of landless farmers-estimated to be around 50-60 million (Yew 2012, p.283). The influx of landless farmers presents an enormous challenge of how to design compensation for land-taking in a way that takes into account the long-term livelihoods of the landless. 
The failure to address this challenge will threaten social stability, one of the key concerns of the communist party.

It is generally believed that affected farmers are victims in China's urbanization process, as they are deprived of their primary means of production and left in destitution (Guo 2001; Cai 2003; Liu, Fang and Li 2014). By institutional design, land requisition is a coercive decision by the state, causing farmers difficulties in contesting the official decision. Based on field research in more than 20 provinces, the Ministry of Land and Resources (2003) found that inadequate compensation to affected villagers prevailed; what's worse, some local governments siphoned land compensation fees for other purposes, leading affected villagers not able to receive the full amount of promised compensation. From 1999 to 2004, affected farmers were owed at least 17.5 billion RMB in arrears (Ministry of Land and Resources 2004). While it is true that farmers' economic and social interests have been threatened due to land requisition-and I have no intention to deny this-this general picture may disguise a rather complex and diversified rural reality during China's urban sprawl. Yep (2013) reminds us of a bifurcated rural society where farmers, whose income is heavily dependent on land, are strongly against land requisition, but farmers in the more prosperous regions, blessed with non-agricultural job opportunities, have strong incentives to give up their land. As a result, their conflicts with the government are not triggered by land requisition, but by the amount of compensation. Empirically, compensation for land taking varies significantly across subnational units. Some villages in wealthy provinces like Beijing reap sizeable benefit and generate wealth for villagers by directly engaging in the urban land market, technically an illegal action (Su, Tao and Wang 2013). Based on a few case studies, Peimin (2007) observed that landless farmers in some localities were provided with pensions, medical insurance, and employment arrangements, in addition to cash compensation payments (p.146). These studies offer a useful point of departure. Using an original survey of over 2000 rural households, this study systematically examines why some local governments provide landless farmers with social welfare benefits, while others do 
not.

China is an interesting case for examining rural social welfare provision for landless farmers. While it is understandable that the central government has an incentive to take care of landless farmers in order to mitigate the urban-rural gap and maintain social stability, the center depends on local governments to provide a wide range of social welfare benefits - including, but not limited to, pensions, health care, and unemployment insurance. However, local governments are financially squeezed by the central government under the existing fiscal arrangements and consequently face substantial budget deficits, creating difficulties in providing public goods and social welfare benefits (World Bank 2002; Oi and Zhao 2007; Wong 2009). Politically, in China, where meaningful elections are still lacking, the career prospects of local officials are determined primarily by a performance-based evaluation system that focuses heavily on promoting local economic growth, but not so much on social welfare provision (Edin 2003; Landry 2003, 2008; Whiting 2004; Li and Zhou 2005; Xu 2011). These economic and political conditions facing local politicians make the Chinese case more puzzling. Why do some local politicians, who are neither economically empowered nor politically motivated, provide landless farmers with social welfare benefits?

I argue that the implementation of the land for welfare program cannot be understood in isolation from the profound urban-rural gap in land property rights arrangements and social welfare provision in China. The dual land tenure system, inherited from Mao's communist past, allows local officials to generate revenue by expropriating rural land, which, to rural households, has social insurance as well as income-generating functions. In the process of land requisition, farmers who become landless are provided with social welfare benefits to compensate for their loss of land's insurance function. Such provision, however, is not developed out of local governments' benign intention, but their strategic reaction to the central government's development program that combines rural 
social welfare provision with a land rewarding system, which provides an opportunity for local officials to gain more land. Rural social welfare benefits are provided in a selective manner: the access to welfare benefits is not universal, but biased towards land-losing villagers; local officials have chosen the welfare benefits that are less costly for them to provide, typically in the form of a pension insurance.

The rest of the article is organized as follows. Section 2 examines the dual structure of urban-rural development in China with a focus on the land tenure system and social welfare provision. Section 3 theorizes the land for welfare trade mechanism and derives hypotheses. Section 4 examines various local government initiatives in implementing the land for welfare program. Section 5 provides multilevel analysis combining data from the 2008 China Survey and original data I compiled from a variety of archival sources. Section 6 concludes.

\section{The Urban-Rural Divide in China}

\subsection{Dual Land Tenure System}

A legacy of the Communist past, land is segmented into urban land and rural land, with each governed by significantly different systems of property rights. Formally, urban land is owned by the state while rural land is owned by rural collectives. In the communist era, land was not viewed as a commodity; instead, it was allocated administratively, free of charge. As economic reforms proceeded, land markets were developed to trade land use rights so as to accommodate foreign investors, but exposing land transfers to market forces

has been largely constrained in the urban land market (Lin and Ho 2003; Perkins 2009). The urban land market consists of a primary market and a secondary market. In the primary land market, the state monopolizes the supply of land and leases out land primarily through three major conveyance methods: negotiation, bid invitation, and 
auction (The State Council 1990, Article 13). By paying required taxes and fees associated with land conveyance, land users gain the right to use land for a fixed period of time that varies according to the purposes of land use. Land users also gain the right to participate in the secondary market where they may transfer land use rights to others, rent their land to others, or use their land use rights as collateral. In rural areas, however, land use rights cannot be legally purchased or sold on the open market, although a black market has been pervasive where state agencies and rural collectives are the primary violators that illegally occupied, sold, or transferred land without going through state requisition (Lin and Ho 2005; Su, Tao and Wang 2013).2 Thanks to the household responsibility system introduced in the early 1980s, farmers gained the right to use land and to claim residual income generated from their designated land, but they do not have the right to convert agricultural land to non-agricultural use (Lin 1992). The time guaranteed for rural households to use their designated land was extended from originally 3 years to 30 years by 1993 (Lin and Ho 2003, p.698-699). Since 2013 farmers have been allowed to permanently hold onto such rights (Chinese Communist Party (CCP) Central Committee, 2013, Article 20). These increasingly extending lengths for farmers to hold land have significantly improved the security of rural land tenure and contributed to a dramatic increase in agricultural output (Kung 1995, 2000); however, they have failed to prevent local authorities from arbitrarily seizing land from farmers. The Property Rights Law (2007) gives the state an authority to override individual land use rights for the sake of "public interest" (article 42), the term of which is not clearly defined and often leads to abuses of power by local authorities in land requisition (Guo 2001; Cai 2003).

Perhaps the fundamental institutional arrangement that further contributes to the segmented land tenure system is the exclusion of farmers' participation in land conveyance.

\footnotetext{
${ }^{1}$ Urban land use rights can be claimed for 70 years, 50 years, and 40 years when urban land is used for residential, industrial, and commercial purposes, respectively. The State Council 1990, Article 12.

${ }^{2}$ Individual farmers are also involved in illegal land-related activities, but they were responsible for only a small fraction of the total land illegally occupied. See, for example, Lin and Ho, 2005.
} 
Instead, rural land must first be acquired by the state in order to be legally transferable in the primary land market. When land is acquired by local authorities, affected rural households are supposed to receive land-taking compensation. However, without a well-functioning rural land market, land-taking compensation is calculated based on the annual agricultural output value prior to land requisition without taking into account the land's future market value (Land Administration Law 2004, Article 47). When the acquired land is resold in the primary market where local authorities hold a monopoly power in land supply, the price is determined on the basis of land's future use - land generally used for industrial, residential, or commercial purposes - using a market approach (e.g., bid invitation and auction). The market determined price that commercial land users paid to local authorities far exceeds the lump sum land-taking compensation eventually received by affected farmers (Tao et al. 2010, p.2224). A recent survey of 1,791 rural households across 17 provinces reveals that local authorities paid farmers an average compensation of approximately $\$ 17,850$ per acre, but resold the land to commercial users at an average of $\$ 740,000$ per acre, more than 41 times the land-taking compensation average (Economy 2012).

The segmented land markets are formulated largely by design; more importantly, the price differential arising from such distorted markets are captured by local state authorities, rather than farmers - the original land users - therefore forming a strong revenue motive for local governments to expropriate rural land for conveyance to commercial users. Accompanying this conversion from rural land to non-agricultural use are rapid urban expansion, mushroom growth of economic development zones, and massive loss of arable land (Lin 2009; Yew 2012). Shocked by the magnitude of land loss, the Chinese government substantially revised the Land Administration Law in 1998. Under this new regulatory framework, lots of land-use decision making power previously vested in county- and prefecture-level governments are transferred upward to the central or provincial governments (Lin and Ho 2003, pp.693-696). The center introduced mandatory 
land quotas - the amount of land to be used for construction, the amount of conversion from agricultural land to non-agricultural use, and the amount of farmland to be preserved - and allocated these quotas top-down along the administrative hierarchy: the central government sets national quotas and disaggregates them to provinces; each province then

disaggregates its quotas to its municipalities, and each municipality to its counties (The State Council 1998, Article 13). The implementation of land quota instruments puts pressure on local authorities to convert agricultural land to non-agricultural use and motivates them to come up with various solutions to circumvent these restrictions (Wang, Tao and Tong 2009; Wang et al. 2010; Zhang et al. 2014).

\subsection{Dual Track Welfare Structure}

Perhaps the most important administrative barrier separating urban and rural populations in China is the household registration system, or hukou, implemented in 1955, which identifies a person with a specific location and a status, either urban or rural. The status of one's hukou defines what welfare entitlements an individual receives, with rural hukou holders receiving considerably fewer social welfare benefits than urban hukou holders (Cheng and Selden 1994; Knight and Song 1999; Wang 2005; Whyte 2010). In the socialist era, urban residents were bound to their place of employment, the "work unit." Almost all work units were converted to state ownership and became a formal hierarchy subject to direct state control. The work unit guaranteed its regular workers lifetime employment and attendant welfare benefits including rationed allotments of food and consumer goods, health care, pensions, education, housing, and death benefits. In contrast, collective ownership was the predominant form of ownership in rural areas. Rural residents were organized through their collectives, which, unlike the state-financed urban work unit, were not part of the state hierarchy and thus had no claim on national resources. Consequently, rural collectives had to rely on nothing but local resources and labor power. They could provide rural residents with welfare benefits only if they generated a surplus, which was 
difficult, if not impossible, as they were compelled to sell agricultural products to the government at artificially low, bureaucratically set prices. With limited resources available, rural collectives provided grain, clothing, and housing only to those who lacked familial networks to provide them (Selden and You 1997). Such urban-rural inequalities in access to welfare benefits were largely locked in because an individual's hukou status to which welfare entitlements are attached was nearly impossible to change (Cheng and Selden 1994).

In the reform era, escalating costs of delivering welfare benefits to a growing number of retirees and increasing pressure to compete with rapidly growing non-state enterprises spurred efforts to transform the comprehensive welfare package in urban areas, while the countryside remained largely left on its own in financing welfare benefits (Selden and You 1997). Nonetheless, the form of self-help welfare provision in the context of economic reforms generated a large variation in welfare and social services provided in rural areas. In impoverished villages that possess little revenue from industry or other resources, rural collectives took a predatory form of extracting resources available from local populations and welfare services were largely absent. In contrast, villages where village cadres could extract revenue from local industries - in the form of private, collective, and foreign-financed firms - public services and welfare are improved, but restricted to local residents only (Unger and Chan 1999; Smart and Smart 2001). Essentially, the hukou system, as the fundamental institution that divides residents into urban and rural populations and into local and non-local populations, remains potent and intact in the process of economic reforms (Chan and Buckingham 2008). Constrained by the hukou status, rapidly growing rural migrant workers, who flow into urban cities with the relaxation of restrictions on rural-to-urban mobility, are consistently excluded from urban social welfare benefits. Economic reforms unfortunately failed to mitigate the sharp urban-rural gap. In a nationwide survey of over 3,000 households conducted in 2008, respondents were asked if they have unemployment insurance and pensions. About 26

\footnotetext{
${ }^{3}$ Author's dataset. More description on the China survey is provided in Section 5 Data and Analysis.
} 
percent of urban residents have unemployment insurance and 57 percent have pensions. In contrast, only 3 percent of rural residents have unemployment insurance and 9 percent have pensions. Whyte (2010) describes the profound urban-rural gap in China as a "caste-like division" that creates "one country, two societies" (p. 5).

\section{The Logic of Land for Welfare in China}

Politicians care about their careers and Chinese politicians are no exception. Being in power allows political leaders to allocate goods and, when possible, retain resources for their own personal use. In China, the career prospects of leading government officials are determined largely by their performance, evaluated regularly based on a set of criteria commensurate with the preferences of Party goals (Tsui and Wang 2004; Whiting 2000, 2004). The performance targets used as the evaluation criteria are not weighted equally, but are biased toward generating local revenue and promoting local economic development (Edin 2003; Landry 2003, 2008; Li and Zhou 2005). Recent statistical analyses shows that provincial-level officials who contribute more revenue to the central government are more likely to be promoted (Sheng 2010; Shih, Adolph and Liu 2012). Land provides local officials with a source of revenue, an instrument with which to intervene in the economy, and a collateral used to apply for bank loans necessary for building local infrastructure (Tao et al. 2010; Whiting 2011). All these land-generated functions help local officials improve their performance specified in the evaluation system, potentially increasing the chance of career advancement. As a result, local officials have a strong incentive to take advantage of the distorted land markets by expropriating rural land for conveyance to commercial land users.

Under the dual track welfare structure, land provides rural residents with a source of income and social insurance. Knowing land is a last resort to generate income, rural residents dare to migrate to cities for higher-income jobs, thereby promoting rural labor 
mobility in China (Yao 2004). When rural residents are too old to farm, they can generate income by renting their land to someone who can farm. In this context, land functions as a pension for the elderly in rural areas. As such, when rural land is expropriated, villagers lose a source of social security as well as an income-generating asset.

However, the current land-taking compensation prescribed by state law and regulations fail to take into account land's social security function. Instead, it is limited to three elements: compensation for the loss of arable land, relocation expenses, and compensation for the loss of on-site property and agricultural products (Land Administration Law, Article 47). Land-taking compensation typically takes the form of a one-time monetary payment, the calculation of which is based on annual agricultural output value prior to land requisition while land's future market value is almost entirely ignored. Empirically, some local governments have found this form of compensation problematic. The Land and Resource Bureau of Foshan, Guangdong province, in its report on local land expropriation, states: "The drawback of [one-time] monetary compensation is that it is difficult to provide land-losing farmers with a basic living in a long run. Once their compensation is exhausted, they are likely to ask the government for more money. This creates a potential burden for the government and also affects rural stability" (Foshan Bureau of Land and Resources 2008). Similarly, after receiving a large amount of land-taking compensation in cash all at once, many villagers do not know how to spend it wisely and sometimes exhaust the compensation very quickly, an issue mentioned by several local officials while I conducted fieldwork. To facilitate land taking, local governments may have an incentive to explore alternative compensation methods, one of which is to provide affected farmers with some social welfare benefits, in addition to one-time cash payments, to compensate for their loss of social security due to land requisition. Following this logic, we expect that:

Hypothesis 1: Farmers who experienced land expropriation are more likely to 
receive welfare benefits than those whose land has not been taken.

The land for welfare program as an alternative to one-time cash compensation is expected to be welcomed by many affected farmers who have been denied access to welfare benefits for decades; however, this program is not the only alternative available to politically driven local officials, who have multiple alternative compensation forms and are more likely to choose the one that satisfies their administratively superior or higher level government authorities rather than ordinary citizens under the authoritarian setting. The $\mathrm{Hu}$ Jintao Administration promoted to build a "harmonious socialist society" by enabling the disadvantaged groups and less developed regions to benefit from economic growth in order to address the increasing social injustice and inequality as a result of three decades of economic reforms (Fan 2006). The so-called "Central Document No. 1" - the first policy document issued every year by the Central Committee of the Communist Party and the State Council that outlines the top priority for the coming year - focused on rural issues since 2004. To address the profound urban-rural gap, the central government promotes the "Unified Management of Urban and Rural Areas" (UMURA, chengxiang tongchou). In doing so, the central government calls for "properly allocating land-losing farmers, providing them with social security" (CCP Central Committee and the State Council, 2003, Article 16), "exploring the rural pension system corresponding to the level of local economic development, ... establishing a system of providing guaranteed minimum living benefits if conditions permitted" (CCP Central Committee and the State Council, 2005, Article 22), "encouraging local governments to conduct experiments in rural pension provision" (CCP Central Committee and the State Council, 2007, Article 5), and "improving social security of land-losing farmers" (CCP Central Committee and the State Council, 2009, Article 15). The call for rural social welfare provision reveals the central government's preferences, but unlike the state mandates (e.g., revenue collection), it is not incorporated into the cadre evaluation system; and as a result, under China's highly decentralized system of fiscal management and administration, the agenda on reducing the 
urban-rural gap alone - despite being promoted by the central government - may not provide a sufficient motive for local governments to take action towards rural social welfare provision.

However, the problem of lack of incentive can be cured by combining the welfare program with a reward on urban construction land. Another key element under the UMURA framework deals with land by permitting local politicians to link the contraction of rural construction land with the expansion of urban construction land. Rapid industrialization and urbanization have produced so-called "hollowed villages" (kongxin cun) in China, where a significant number of houses, typically located in village core, become uninhabited or abandoned due to rural-to-urban migration or house relocation from village core to periphery (Long et al. 2012). Villages that are being hollowed out create a source of land for non-agricultural use in urban areas: the local government first demolishes rural houses, which occupies rural construction land, and reclaims the land to arable land - a process that makes previously occupied construction land unoccupied; the government then "relocates" the land to urban areas, with the relocated area equivalent to the amount of rural construction land being reclaimed to arable land. That is, the contraction of rural construction land is now linked with the expansion of urban construction land, the process of which is essentially a land spatial rearrangement by converting rural collective land ownership to urban state ownership while maintaining the total amount of construction land unchanged. Conceptually, doing so increases land use efficiency and, to some extent, relieves local pressure on scarcity in urban construction land, arguably a win-win outcome for both related rural collectives and local governments.

To implement the program, China continues with the experimental approach by which local innovations are first implemented as pilot projects within a few localities and only those proven to produce desired outcomes are then diffused to more localities and may eventually become national policy (Montinola, Qian and Weingast 1995; Heilmann 
$2008 a, b)$. The experimentation process is neither completely top-down nor bottom-up, but involves the interplay between local initiative and central sponsorship (Heilmann 2007). In experimenting rural-to-urban land conversion, the central government specifies four conditions as the criteria to determine if a local application for the pilot status can be approved. First, the conflict between the demand for and supply of (urban) construction land must be substantial. The local rural construction land must have great potential to be reclaimed. Second, both the local government and villagers must be enthusiastic about the pilot project. Third, the locality must have relatively rapid economic development and must be able to self-fund the pilot project. Fourth, the local government must strictly follow land regulations, but also be creative in institutional innovation (Ministry of Land and Resources 2008, Article 11). Among the four conditions, the first and third are easier to be measured and may therefore be more crucial in determining a locality's qualification. To ensure rural areas can benefit from this experiment, the central government requires a portion of the revenue, generated from rural-to-urban construction land conversion, be returned to the affected rural area (Ministry of Land and Resources 2007a, Article 4).

From the local government perspective, local politicians are interested in experimenting with rural-to-urban construction land conversion because this program helps them, to some extent, get around the land quota restriction: quotas cap the amount of agricultural land that can be converted to urban construction land, but they do not apply to the rural-to-urban construction land conversion, a process by which land ownership is converted from the rural collective to the urban state, while the land type (i.e., construction land) remains unchanged. As a result, local politicians obtain additional construction land without taking up construction land quotas; but to do so they must acquire rural-to-urban construction land "operating quotas" (zhouzhuan zhibiao), available only for authorized localities. The process of granting the UMURA experimental status is incremental in nature, a typical pattern of policy diffusion in China: the central government authorized 8 provinces to implement the program by 2005 and had gradually expanded to 12 provinces 
by 2007 and 24 provinces by 2009. 1 Figure 1 provides a map highlighting the provinces that were granted to the UMURA pilot status. Under the UMURA program, rural-to-urban construction land conversion and provision of rural social welfare benefits are bundled together. To gain pilot status, local governments are incentivized to provide rural social welfare benefits to signal to the central government that rural residents are taken care of during and after land requisition. Therefore, we would expect that:

Hypothesis 2: Farmers from localities granted the "UMURA pilot status" are more likely to receive welfare benefits than those from localities without the pilot status.

Given the enormous size of the rural population, universal coverage of rural social welfare would impose a financial burden on local governments. Since land functions as social insurance, local politicians from experimental sites may give priority to land-losing farmers in welfare delivery. We therefore expect that:

Hypothesis 3: Land-losing farmers from localities granted the UMURA experimental status are more likely to receive welfare benefits than those who still own land in the same localities and those from non-experimental sites regardless of their land expropriation status.

Moreover, the distribution of land-generated revenue is a zero-sum game: the more benefits rural households received, the less revenue local politicians retain. While local officials in pilot localities promise to provide social welfare benefits, they have incentives to minimize the cost associated with their delivery; as a result, they are more likely to deliver social welfare benefits that are less costly.

Hypothesis 4: Land-losing farmers from localities granted the UMURA experimental status are more likely to receive welfare benefits that are less costly for the local government than to receive welfare benefits that cost more.

\footnotetext{
${ }^{4}$ By 2007 the experimental provinces include Tianjin, Shanghai, Inner Mongolia, Jiangsu, Zhejiang, Anhui, Shandong. Henan. Hubei. Guangdong. Sichuan, and Chongqing. See Ministry of Land and Resources 2007b; Chongqing Development and Reform Commission 2010.
} 
Figure 1: Provinces with Pilot Status (2007)

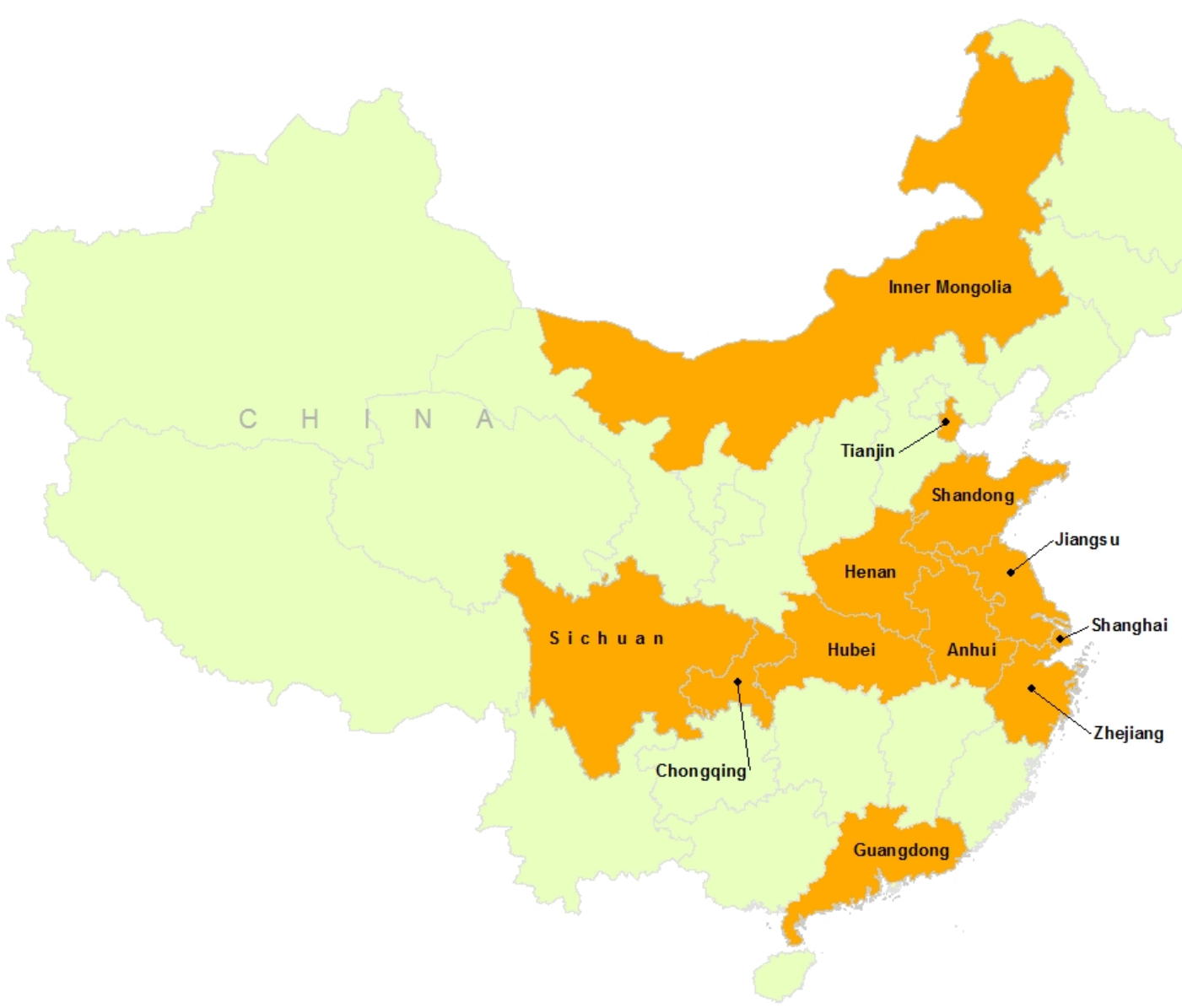

Source: Ministry of Land and National Resources, Notification on further Regulating Experimentation of Linking the Contraction of Rural Construction Land with the Expansion of Urban Construction Land, July 13 2007. Chongqing Development and Reform Commission, Chongqing Experiment, 2010 .

\section{Varieties of Local Land for Welfare Initiatives}

Richer and more developed localities are expected to be more incentivized to explore new compensation methods in the land requisition process, because in such localities, the simple one-time cash compensation calculated according to the formula prescribed by the state regulations is hardly possible to satisfy the affected rural residents who can easily calculate the difference between the monetary compensation they will receive and the skyrocketing market price of the land that was previously "owned" by them but later is taken by the 
state. This gap is likely to be larger in more developed area where the local economy drives the price of land to be more expensive in the primary urban land market. Perceiving this gap, affected rural residents in these localities are more likely to develop grievances against land requisition and may even take action (e.g., petition and protest) to prevent their land from being expropriated. Local officials in these localities are interested in converting more rural land for urban use to accommodate the local economy and developing alternative compensation schemes to ease the pressure coming from affected rural households during land requisition. Both goals can be fulfilled by the UMURA design. From the central government perspective, it is also in its best interest to authorize relatively rich localities to implement the UMURA program because such local experimentation helps the center explore ways of mitigating the increasing urban-rural gap, with all associated expenses paid by local governments rather than by the center. From the map (Figure 1), provinces with the UMURA pilot status are concentrated in the east coast and in the central region, with only two provinces (i.e., Chongqing and Sichuan) located in the western region, largely confirming the expectations.

Zhejiang, a southeast coastal province bordering Shanghai to the north, is the second richest province behind only Shanghai. The vibrant local economy in Zhejiang creates high demand for land that significantly exceeds the supply of land quotas distributed from the center (Wang, Tao and Tong 2009; Wang et al. 2010; Zhang et al. 2014), thereby driving land prices up and consequently generating windfall revenues. In 2008, one hectare of land in Zhejiang could generate an average land transfer fee as high as 9.69 million RMB, just below the three provincial-level municipalities of Beijing, Shanghai, and Tianjin (Ministry of Land and Resources 2009, p. 171). The total land transfer fee accounted for 53 percent of budget revenue in Zhejiang (Ministry of Finance 2009, p. 405). To overcome its land scarcity problem, Zhejiang experimented with "linking the contraction of rural construction land with the expansion of urban construction land," which essentially permits rural-to-urban construction land conversion, a key component of the UMURA 
program.

To facilitate land conversion, the local government in Jiaxing, a prefecture-level city in northern Zhejiang, experimented with a new compensation scheme in 2008 by which villagers who voluntarily gave up their rural housing plots are provided with urban housing - which, unlike rural housing, is trade-able and gives the owner complete control over when, if ever, to sell his house - and villagers who voluntarily give up their agricultural land are provided with pension insurance. The provision of rural pension benefits is financed locally by land transfer fees. In addition, the government provides those who lose land and become jobless with job training and consultation. Agricultural firms and farms that lease agricultural land given up by villagers give priority to local land-losing villagers when hiring (Nanxun Government 2009). In Xiaoshan district of Hangzhou, capital of Zhejiang, provision of pension insurance is associated with the amount of expropriated land. Every $0.5 \mathrm{mu}$ (approximately 0.08 acre) of expropriated agricultural land is associated with one person eligible to receive pension insurance without paying the premium. If the expropriated land is less than $0.5 \mathrm{mu}$, villagers can pay the difference in order to receive a pension insurance. When a rural household's land is expropriated but the amount of expropriated land is not sufficiently large to cover pension insurances for every household member, villagers are surprisingly rational in determining who in their household will get the pension insurance. Husbands usually give the opportunity to their wives, because according to local regulations, women start receiving their monthly pension at age 50 while men must wait until they reach 60 (Xiaoshan Social Security Management Office 2012). A villager explains his calculation, "If my wife takes up the opportunity [of getting pension insurance], she will receive pension benefits for more than 10 years than I would" (Zhao, Hu and Yu 2008, p. 22). Following the same logic, younger people give the opportunity to older people in their household because they will start receiving pension benefits sooner than they will. 
Local officials often have alternative policy options from which they can choose in order to mitigate the urban-rural gap in the process of land requisition. The most straightforward alternative is simply to provide affected rural households with larger one-time cash payments, possibly exceeding the amount prescribed by the state regulations. An immediate question is why local officials might prefer welfare provision to cash payments. Interviews with local officials illustrate their choice: while one-time cash payments require local governments to provide the payments all at once, pension benefits allow them to disperse the cost by only paying those who reach the eligible age, typically 55 for women and 60 for men. By institutional design, officials in China can stay in the same position for no more than two five-year terms. By the end of their second term in office, an official faces one of the following political fates: promotion within the same locality or elsewhere, transfer to a position of identical bureaucratic rank, exit from office if he reaches retirement age, and, in the worst cases, removal from office for some disciplinary reason (e.g., corruption). Empirical studies show that the actual time local officials remain in the same position is less than one institutionally designated term (i.e., 5 years) (Landry 2008; Guo 2009). As a result, providing affected villagers with pension benefits allows local officials to reap all the benefits associated with land requisition, but successive officials incur the cost of welfare provision.

As the map indicates, the formal experimental designation has not been confined to only rich and more developed provinces. Chongqing, a municipality in southwest China that aims to become an important growth pole in western China and an economic hub in the upper reaches of Yangtze River, faced a serious challenge of land quota scarcity. In response, the former party secretary of Chongqing, Wang Yang, initiated the UMURA project. Chongqing was authorized to experiment with UMURA comprehensive reform in 2007, which was continued by Wang's successors, Bo Xilai and later Zhang Dejiang after Bo's removal. 
During experimentation, the Chongqing government encouraged villagers to voluntarily give up their agricultural land and housing plots; those who gave up their land received a compensation package, which combined a monetary transfer with social welfare benefits. These benefits include urban residency, housing resettlement, pension benefits, health care, guaranteed minimum living benefits, and education subsidies for their children. While unemployment insurance is not included in the compensation package, the government provided those who are able and willing to work with free skills training and employment consultation. In addition, villagers continued to receive dividends generated from their collectively-owned properties managed by their rural collectives (Party committee of Jiulongpo District, Chongqing 2007). The local government then pooled together all agricultural land given up by villagers and leased out land to large-scale land users, who can take advantage of economies of scale. For example, the local government of Jiulongpo District, Chongqing collected 407 hectares of agricultural land from 2,300 villagers and leased out the land to over 100 firms to grow flowers, according to an official report circulated within the government.

Another key element of the Chongqing UMURA experiment was the Rural Land Transaction Center (RLTC, nongcun tudi jiaoyisuo), a market established by the Chongqing government with the authorization from the central government in December 2008 where rural construction land quotas - locally called "land tickets"(dipiao) - are converted into urban construction land quotas through auction. Since 2009, the Chongqing government stopped distributing land quotas to those who use land for commercial and residential purposes in its main urban districts. As a result, these land users are forced to acquire land quotas through auction at the RLTC, a process that generates revenue for the government. As of May 2010, 85 land tickets had been transferred, entailing a total 18,000 $m u$ (approximately 2,965 acre) of construction land, with the transaction price totaling 1,865 million RMB (Chongqing Daily 2010). According to my interview with an official from the UMURA reform office in Chongqing, about 30 percent of the revenue generated 
from land ticket transaction must be returned to the villages where land quotas are originally generated to pay for compensation packages. In addition to the revenue benefits, directing a portion of land users to acquire land quotas via the RLTC allows the Chongqing government to save more land quotas for manufacturing industries, a source of steadier tax revenue.

In sum, the actual implementation of land-for-welfare exchanges varies across localities. In Zhejiang and Chongqing where both were authorized to experiment with the UMURA reform, local governments provided rural residents with social welfare benefits. Despite the center's call for the provision of rural welfare benefits, these benefits have been provided in a highly selective manner at the local level. For one, access to benefits is not universal, but is biased toward land-losing villagers. Second, among various welfare benefits, pension benefits are generally preferred by local officials who are cost-sensitive. While a nontrivial portion of land revenue must be used to deliver rural social welfare benefits, local officials remain a big winner in the land for welfare program due to various benefits associated with land requisition.

\section{Data and Analysis}

This section turns to statistical analysis to test if the logic of land for welfare holds in a larger context. The analysis requires data at both the individual and locality levels. At the individual level, I use the China Survey, a collaborative project between Texas A\&M University and Peking University, conducted from April 2 through June 5, 2008. The survey is a stratified multi-stage probability sample of 3989 households, covering 59 municipalities in 26 provinces. 5 Sampled households consist of 2992 rural residents and 977 urban residents. This paper uses rural residents, a subset of the sample, in the analysis. At the locality level, I take municipality as the level of analysis due to data availability; I

\footnotetext{
${ }^{5}$ The China Survey questionnaire can be found at its website: http://thechinasurvey.tamu.edu.
} 
compiled a dataset for 59 municipalities to match the respondents in the China Survey.

The dependent variable, social welfare provision, is measured by pension insurance at the individual level. The survey asks the following question: "Except for commercial insurance you personally purchased, do you have pension insurance?" The answer is measured dichotomously: 1 for yes, 0 for no. The independent variables of interest include land expropriation, the experimental status of the locality, and their interaction term. Land expropriation is measured at the individual level using the following survey question: "Did your household experience requisition of land property or resettlement in the past?" The answer is coded dichotomously: 1 for yes, 0 for no. Experimental status is measured at the locality level, using an indicator of whether the province where each municipality is located received the UMURA experimental status. The estimated models are specified as follows:

$$
\begin{gathered}
\operatorname{logit}\left\{\operatorname{Pr}\left(y_{i j}=1\right)\right\}=\beta_{0}+\beta_{1} x_{1 i j}+\beta_{2} x_{2 j}+\mathbf{I}_{i j}^{\prime} \boldsymbol{\alpha}+\mathbf{R}_{j}^{\prime} \boldsymbol{\gamma}+\xi_{i j} \\
\operatorname{logit}\left\{\operatorname{Pr}\left(y_{i j}=1\right)\right\}=\left(\beta_{0}+\zeta_{j}\right)+\beta_{1} x_{1 i j}+\beta_{2} x_{2 j}+\mathbf{I}_{i j}^{\prime} \boldsymbol{\alpha}+\mathbf{R}_{j}^{\prime} \boldsymbol{\gamma}+\epsilon_{i j} \\
\operatorname{logit}\left\{\operatorname{Pr}\left(y_{i j}=1\right)\right\}=\left(\beta_{0}+\zeta_{j}\right)+\beta_{1} x_{1 i j}+\beta_{2} x_{2 j}+\beta_{3} x_{1 i j} x_{2 j}+\mathbf{I}_{i j}^{\prime} \boldsymbol{\alpha}+\mathbf{R}_{j}^{\prime} \boldsymbol{\gamma}+\epsilon_{i j} \\
\operatorname{logit}\left\{\operatorname{Pr}\left(y_{i j}=1\right)\right\}=\left(\beta_{0}+\zeta_{1 j}\right)+\left(\beta_{1}+\beta_{3} x_{2 j}+\zeta_{2}\right) x_{1 i j}+\beta_{2} x_{2 j}+\mathbf{I}_{i j}^{\prime} \boldsymbol{\alpha}+\mathbf{R}_{j}^{\prime} \gamma+\epsilon_{i j}
\end{gathered}
$$

Where $i$ indexes villagers and $j$ indexes the 59 municipalities. The variable $x_{1}$ is land expropriation at the individual level and $x_{2}$ is experimental status at the municipal level. $\beta_{1}, \beta_{2}, \beta_{3}$ are coefficients associated with land expropriation, experimental status, and their interaction, respectively. $\mathbf{I}$ is a $12 \times 1$ vector of individual controls, including age, sex, years of education, an indicator of communist party membership, and occupation. $\mathbf{R}$ is a $3 \times 1$ vector of control variables at the municipal level, including level of economic development 
measured by the logarithm of local GDP per capita, government fiscal capacity measured by the ratio of budget expenditure to revenue (Lorentzen, Landry and Yasuda 2014), and the impact of globalization measured by foreign direct investment (FDI) as a proportion of local GDP (Huber, Mustillo and Stephens 2008). The impact of globalization is controlled to take into account the theory that the state is more likely to provide social welfare benefits to shield actors in the economy from the fluctuations and volatility of the global market (Katzenstein 1985; Rodrik 1998). $\boldsymbol{\alpha}_{12 \times 1}$ and $\gamma_{3 \times 1}$ are column vectors of coefficients associated with $\mathbf{I}$ and $\mathbf{R}$, respectively. $\beta_{0}$ is the intercept. $\xi_{i j}, \epsilon_{i j}$ are idiosyncratic errors. The error component $\zeta_{j}$ in models 2 and 3 represents a municipality-specific random intercept and $\xi_{i j} \equiv \zeta_{j}+\epsilon_{i j}$. In model 4, the error components $\zeta_{1 j}$ and $\zeta_{2 j}$ represent a municipality-specific random intercept and random coefficient, respectively. The total residual is now: $\xi_{i j} \equiv \zeta_{1 j}+\zeta_{2 j} x_{1 i j}+\epsilon_{i j}$. Detailed variable definitions, sources, and summary statistics for the individual level are presented in Table 1 and for the locality level presented in Table 2.

$$
\text { [Tables } 1 \text { and } 2 \text { about here] }
$$

Model 1 represents simple logistic regressions, taking into account the complex survey structure. To relax the assumption of conditional independence among the responses within the same municipality given the covariates, I estimate the model 2 using a random-intercept logistic regression, which essentially introduces a municipality-specific error component $\zeta_{j}$ in the regression to allow the intercept to vary across municipalities. To test hypothesis 3, I include an interaction term of land expropriation and experimental site indicator in the random intercept model (i.e., model 3). Finally, I estimate a random coefficient model (i.e., model 4), allowing the effects of land expropriation to vary across municipalities. The estimated results are reported in Table 3 .

[Table 3 about here]

In Table 3, both land expropriation and the experimental site indicator have a 
Table 1: Summary Statistics for Individual-level Variables

\begin{tabular}{|c|c|c|c|c|c|c|}
\hline Variable & & Mean & Std. Dev. & Min & $\operatorname{Max}$ & Observations \\
\hline \multicolumn{7}{|l|}{ Key variables } \\
\hline \multirow[t]{3}{*}{ unemployment } & overall & .021 & .144 & 0 & 1 & $\mathrm{~N}=2351$ \\
\hline & between & & .054 & 0 & .294 & $\mathrm{n}=59$ \\
\hline & within & & .139 & -.273 & 1.008 & $\mathrm{~T}-\mathrm{bar}=39.848$ \\
\hline \multirow[t]{3}{*}{ pension } & overall & .081 & .273 & 0 & 1 & $\mathrm{~N}=2500$ \\
\hline & between & & .108 & 0 & .407 & $\mathrm{n}=59$ \\
\hline & within & & .255 & -.326 & 1.062 & $\mathrm{~T}-\mathrm{bar}=42.373$ \\
\hline \multirow[t]{3}{*}{ land expropriation } & overall & .123 & .329 & 0 & 1 & $\mathrm{~N}=2951$ \\
\hline & between & & .113 & 0 & .528 & $\mathrm{n}=59$ \\
\hline & within & & .314 & -.404 & 1.108 & $\mathrm{~T}-\mathrm{bar}=50.017$ \\
\hline \multicolumn{7}{|c|}{ 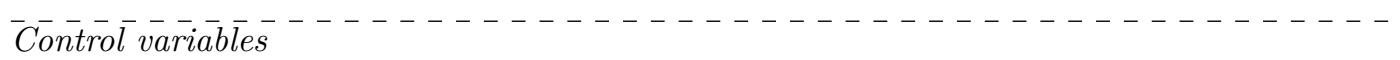 } \\
\hline $\operatorname{sex}($ male $=1)$ & & .478 & .500 & 0 & 1 & 2992 \\
\hline age & & 46.000 & 15.618 & 18 & 92 & 2992 \\
\hline years of education & & 5.278 & 3.882 & 0 & 17 & 2958 \\
\hline Communist Party member & & .048 & .213 & 0 & 1 & 2990 \\
\hline agricultural worker & & .767 & 423 & 0 & 1 & 2657 \\
\hline commerce worker & & .017 & 129 & 0 & 1 & 2657 \\
\hline sole proprietor & & .068 & .253 & 0 & 1 & 2657 \\
\hline private entrepreneur & & .008 & .089 & 0 & 1 & 2657 \\
\hline industrial worker & & .072 & .258 & 0 & 1 & 2657 \\
\hline Party or govt official & & .006 & .080 & 0 & 1 & 2657 \\
\hline enterprise manager & & .004 & .061 & 0 & 1 & 2657 \\
\hline professional & & .015 & .123 & 0 & 1 & 2657 \\
\hline
\end{tabular}

Source: The China Survey, 2008 


\section{Table 2: Summary Statistics for Municipality-level Variables}

\begin{tabular}{|c|c|c|c|c|c|}
\hline \multicolumn{6}{|c|}{ Variable definition and sources } \\
\hline G'̄ōbalization & \multicolumn{5}{|c|}{$\begin{array}{l}\text { Foreign direct investment as proportion of local } \overline{\mathrm{G}} \overline{\mathrm{DP}} \\
\text { China City Statistical Yearbook, } 2009 .\end{array}$} \\
\hline Budget deficit & \multicolumn{5}{|c|}{$\begin{array}{l}\text { The ratio of budget expenditure to budget revenue. } \\
\text { China City Statistical Yearbook, } 2009 .\end{array}$} \\
\hline GDP per capita & \multicolumn{3}{|c|}{ Logarithm of local GDP per capita. } & \multicolumn{2}{|c|}{ China City Statistical Yearbook, 2009.} \\
\hline Experiment & $\begin{array}{l}\text { Dichotomol } \\
\text { Ministry of } \\
\text { Regulating } \\
\text { with the Ex } \\
\text { Developmer }\end{array}$ & $\begin{array}{l}\text { dicator of } \\
\text { d and Resc } \\
\text { erimentati } \\
\text { sion of Urb } \\
\text { ad Reform }\end{array}$ & \multicolumn{2}{|c|}{$\begin{array}{l}\text { Regulating Experimentation of Linking the Construction Land } \\
\text { with the Expansion of Urban Construction Land; Chongqing }\end{array}$} & $\begin{array}{l}\text { a Land } \\
\text { ring } \\
\text { riment }\end{array}$ \\
\hline \multicolumn{6}{|c|}{ Summary Statistics } \\
\hline Vàriable ${ }^{\circ----1}$ & $\bar{M} \overline{\text { eann }}$ & $\overline{\text { Std. }}-\overline{\text { Dev. }}-$ & $\bar{M}^{-} \bar{n}^{-}$ & $\bar{M} \overline{\text { Max }}-\overline{-}$ & $-\overline{\mathrm{Obs}}-$ \\
\hline Globalization & 0.187 & 0.198 & 0 & 0.908 & 59 \\
\hline Budget deficit & 2.973 & 2.278 & 0.869 & $13.196^{*}$ & 59 \\
\hline GDP per capita & 9.927 & 0.776 & 8.189 & 11.540 & 59 \\
\hline Experiment & 0.441 & 0.501 & 0 & 1 & 59 \\
\hline \multicolumn{6}{|l|}{ Correlations } \\
\hline & Globàlizatic & $\overline{\text { Deficit }}-\bar{t}$ & $\begin{array}{c}{ }^{-} \overline{\mathrm{GD}} \overline{\mathrm{P}}^{-} \\
\text {per capit }\end{array}$ & $\overline{\text { Experin }}$ & \\
\hline Globalization & 1.0000 & & & & \\
\hline Deficit & -0.4128 & 1.0000 & & & \\
\hline GDP pe & 0.4344 & -0.7410 & 1.0000 & & \\
\hline Experiment & 0.2043 & -0.1894 & 0.3493 & 1.0000 & \\
\hline
\end{tabular}

*Note: The variable budget deficit has one outlier, 13.196, for Dingxi municipality in Gansu province. Its ratio of budget expenditure to budget revenue was 11.772 in 2007 and 14.421 in 2009. This consistent pattern suggests this outlier is not caused by error. All analyses reported in this paper include respondents from Dingxi. I reran all the analyses excluding the Dingxi respondents; results (i.e., sign and statistical significance) remain unchanged. 


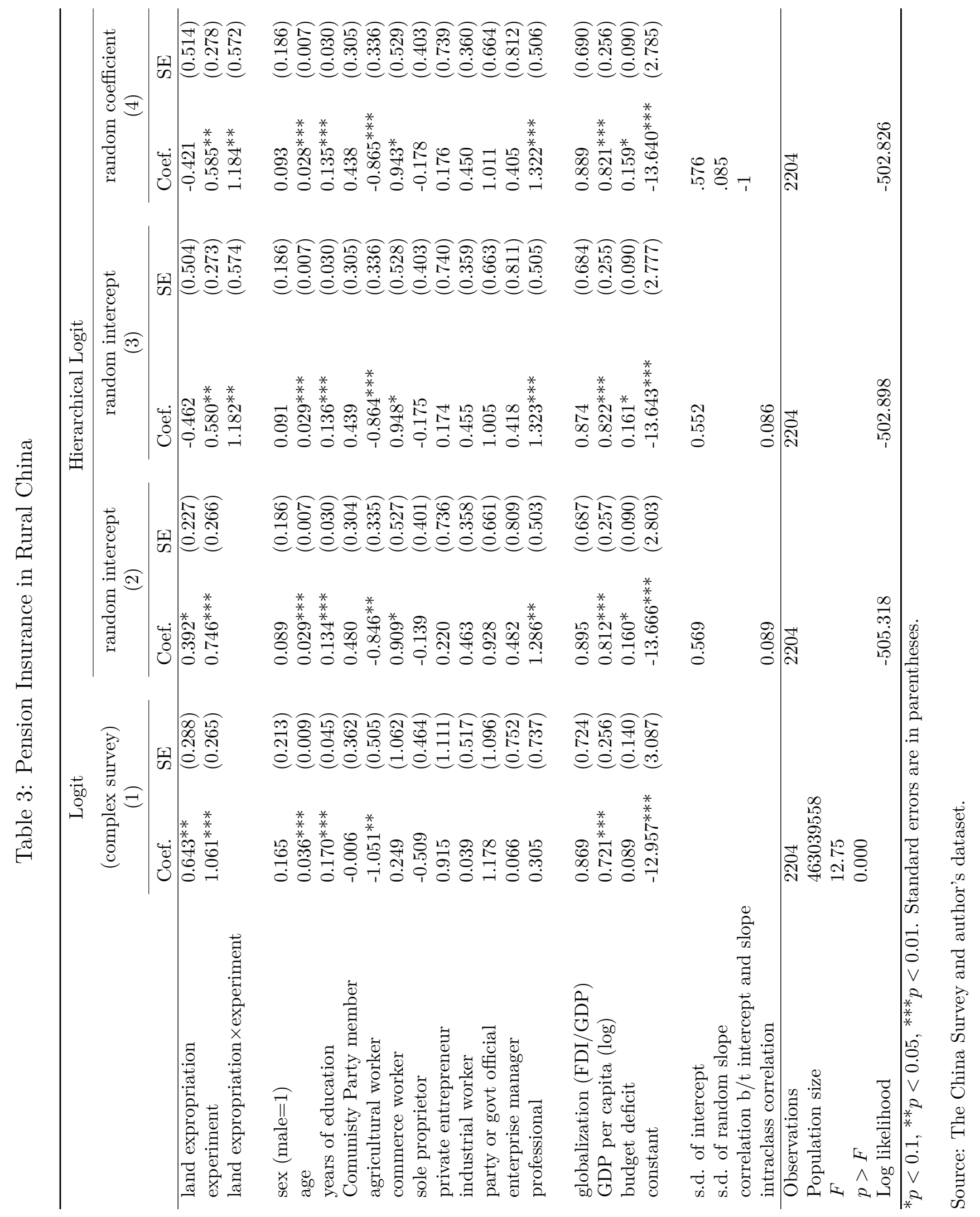


positive, statistically significant association with pension insurance when the interaction term is not included, confirming the first and second hypotheses. The coefficient of land expropriation becomes statistically insignificant once the interaction term is included, but the interaction term itself is statistically significant at the 5 percent level. These results suggest that not all land-losing villagers receive pension insurances. Rather, land-losing villagers from experimental sites have a higher probability of receiving pension insurances, supporting the hypothesis 3. Using the results estimated in model 3, the predicted probability of receiving a pension insurance is 3.4 percent for villagers who did not experience land expropriation at non-experimental sites, holding everything else at their mean values. This probability increases to 11.3 percent for villagers whose land has been expropriated at experimental sites. Holding land expropriation at one and everything else at their mean values, a villager living in a locality with experimental status increases his probability of receiving a pension insurance by 9.2 percent.

The analysis conducted here tends to underestimate the effect of land expropriation on pension provision. The estimation in the analysis only considers the situation where local governments offer social welfare benefits and villagers accept. There is another possibility. Villagers may reject the offer of social welfare provision for a number of reasons. Some villagers may doubt the credibility of the offer and want to wait and see. Alternatively, the welfare benefits provided by local officials may still not be attractive enough for villagers to give up their land. Anticipating that land will become more valuable tomorrow than it is today, villagers, if allowed, may choose to keep their land and reject the offer of the compensation package. While the data do not allow us to consider the situation where villagers reject, I anticipate the effect of land expropriation on social welfare provision will be greater than suggested by the estimation conducted here.

To test the hypothesis that local government officials are cost sensitive and are likely to provide affected rural residents with social welfare benefits that are less costly (i.e., 
hypothesis 4), I introduce another measure of social welfare benefits, unemployment insurance, which was again measured dichotomously in the China Survey. While pension insurance permits local officials to provide services only when affected rural residents reach to the age retirement, unemployment insurance requires local officials to take action immediately after affected farmers become jobless, due to land requisition. The number of working-age people who would qualify to receive unemployment insurance if provided is expected to exceed the number of those who are eligible to receive pension benefits. In this sense, provision of unemployment insurance is more costly for local officials than provision of pension benefits. Table 4 reports the regression results, suggesting that villagers who experienced land requisition are not compensated with unemployment insurance. The UMURA experimental status has a positive, statistically significant effect on unemployment insurance at the 5 percent level. However, the marginal effect of experimental status on unemployment insurance is not substantively different from zero. Living in a locality with experimental status increases a villager's probability of receiving unemployment insurance by 0.7 percent if he did not experience land expropriation and by 1.2 percent if his land was expropriated, holding everything else at their mean values. These findings are consistent with my empirical observation examined in section 4: local governments from experimental sites provide affected rural residents with job training and consultation, but not unemployment insurance. In general, it is rare for villagers to receive unemployment insurance. Among the 2,351 survey respondents who answered the question, only 50, or 2 percent of respondents, have unemployment insurance, and 34 of them are from municipalities with the UMURA experimental status. The interaction term is statistically insignificant, suggesting land-losing villagers in experimental sites have no privilege in receiving unemployment insurance. The estimated no effect of land expropriation on unemployment insurance is consistent with the hypothesis 4 .

$$
\text { [Tables } 4 \text { about here] }
$$


Table 4: Unemployment Insurance in Rural China

\begin{tabular}{|c|c|c|c|c|c|c|}
\hline & \multirow{2}{*}{\multicolumn{2}{|c|}{$\begin{array}{c}\text { Logit } \\
\text { (complex survey) } \\
(1)\end{array}$}} & \multicolumn{4}{|c|}{ Hierarchical Logit } \\
\hline & & & \multicolumn{2}{|c|}{$\begin{array}{c}\text { random intercept } \\
(2)\end{array}$} & \multicolumn{2}{|c|}{$\begin{array}{l}\text { random intercept } \\
(3)\end{array}$} \\
\hline & Coef. & $\mathrm{SE}$ & Coef. & $\mathrm{SE}$ & Coef. & $\mathrm{SE}$ \\
\hline land expropriation & 0.623 & $(0.411)$ & 0.564 & $(0.397)$ & 0.160 & $(0.798)$ \\
\hline experiment & $1.256^{* *}$ & $(0.477)$ & $0.891^{* *}$ & $(0.393)$ & $0.795^{*}$ & $(0.421)$ \\
\hline land expropriation $\times$ expt. & & & & & 0.568 & $(0.931)$ \\
\hline $\operatorname{sex}($ male $=1)$ & $-0.644^{*}$ & $(0.338)$ & -0.543 & $(0.346)$ & -0.536 & $(0.346)$ \\
\hline age & 0.025 & $(0.016)$ & 0.006 & $(0.014)$ & 0.006 & $(0.014)$ \\
\hline years of education & $0.269^{* * *}$ & $(0.071)$ & $0.204^{* * *}$ & $(0.057)$ & $0.204^{* * *}$ & $(0.057)$ \\
\hline Communist Party member & 0.110 & $(0.855)$ & $0.877^{*}$ & $(0.524)$ & 0.857 & $(0.524)$ \\
\hline agricultural worker & $-1.294^{*}$ & $(0.745)$ & $-0.976^{*}$ & $(0.552)$ & $-0.972^{*}$ & $(0.553)$ \\
\hline commerce worker & 0.785 & $(1.192)$ & 0.833 & $(0.727)$ & 0.881 & $(0.732)$ \\
\hline sole proprietor & -0.773 & $(0.716)$ & -0.904 & $(0.730)$ & -0.909 & $(0.731)$ \\
\hline private entrepreneur $\dagger$ & & & & & & \\
\hline industrial worker & 0.086 & $(0.704)$ & 0.527 & $(0.528)$ & 0.535 & $(0.530)$ \\
\hline party or govt official & 1.657 & $(1.279)$ & 1.023 & $(0.991)$ & 1.072 & $(0.994)$ \\
\hline enterprise manager & 0.329 & $(0.985)$ & 0.807 & $(0.980)$ & 0.786 & $(0.985)$ \\
\hline professional & 0.680 & $(0.925)$ & $1.685^{* * *}$ & $(0.658)$ & $1.719^{* * *}$ & $(0.660)$ \\
\hline globalization (FDI/GDP) & 1.156 & $(1.122)$ & $1.568^{*}$ & $(0.946)$ & 1.560 & $(0.954)$ \\
\hline GDP per capita (log) & 0.463 & $(0.468)$ & 0.480 & $(0.379)$ & 0.486 & $(0.381)$ \\
\hline budget deficit & 0.041 & $(0.183)$ & 0.079 & $(0.161)$ & 0.081 & $(0.161)$ \\
\hline constant & $-11.721^{* *}$ & $(5.548)$ & $-11.045^{* * *}$ & $(4.253)$ & $-11.041^{* * *}$ & $(4.265)$ \\
\hline s.d. of intercept & & & 0.442 & & 0.445 & \\
\hline intraclass correlation & & & 0.056 & & 0.057 & \\
\hline Observations & 2077 & & 2077 & & 2077 & \\
\hline Population size & 437456879 & & & & & \\
\hline$F$ & 11.23 & & & & & \\
\hline$p>F$ & 0.000 & & & & & \\
\hline Log likelihood & & & -174.047 & & -173.851 & \\
\hline
\end{tabular}

${ }^{*} p<0.1,{ }^{* *} p<0.05,{ }^{* * *} p<0.01$. Standard errors are in parentheses.

$\dagger:$ Private entrepreneur is not included in the regressions because of perfect prediction. STATA automatically drops observations with private entrepreneurs coded as 1 in regression 1 . In hierarchical logit regressions 2-4, STATA does not drop these observations but produces infinite coefficient associated with private entrepreneur with infinite standard errors.

Source: The China Survey and author's dataset. 
Individual-level control variables have similar results between the provision of pension and unemployment insurances. Rural residents who are more educated have a higher chance of receiving pension and unemployment insurance. Surprisingly, being a communist party member does not provide privileged access to social welfare benefits. Being an agricultural worker decreases the probability of receiving social welfare benefits, while being a skilled worker or professional increases this probability. Age has a positive, statistically significant effect on pension insurance but not on unemployment insurance. Those who experienced land requisition from localities entitled to experiment with the UMURA program have a higher probability of receiving a pension insurance for various age groups. The positive correlation between age and the probability of receiving pension insurance may suggest two patterns. First, older people are more willing to give up their land when pension insurance is included in a compensation package. Alternatively, as the case studies from Zhejiang indicate, when the opportunity of receiving pension insurance is limited, family members rationally choose to give the opportunity to older people who will receive pension benefits sooner.

Municipality-level control variables exhibit different impacts on the provision of pension and unemployment insurances. The coefficient of globalization is not statistically different from 0 for both forms of insurance. While the theory that globalization promotes provision of social welfare benefits explains the rise of the welfare states in the Western world, the theory may not be applicable to China. Both GDP per capita and budget deficit have positive, statistically significant effects on pension insurance, but not on unemployment insurance. This suggests that providing rural residents with unemployment insurance is rejected even in wealthier localities, confirming that local officials are indeed cost sensitive. Governments from wealthier localities usually run smaller deficits, as indicated by the negative correlation between the two variables shown in Table 2. The positive impact of GDP per capita and budget deficit on pension insurance suggests that pension benefits are more likely to be provided in localities with a greater fiscal burden as 
well as wealthier localities. A possible explanation is that not all UMURA experimental localities are wealthy. As shown on the map in Figure 1, provinces granted the experimental status are not only located along the east coast where the economy is more developed and but also in the western region (e.g., Chongqing and Sichuan).

\section{Discussion and Conclusion}

This article demonstrates qualitatively and quantitatively the affinity between land requisition and rural social welfare provision in China. It offers an alternative explanation of social welfare provision in an authoritarian context, where meaningful elections - the mechanism holding political leaders accountable - are absent. The land property rights regime and the urban-rural gap in social welfare provision, both inherited from the communist past, constitute an institutional context in which state actors are embedded. The dual land tenure system creates an opportunity for local government officials to generate revenue from rural-to-urban land conversion. The profound urban-rural gap in social welfare provision allows local government officials to use social welfare benefits as an instrument to facilitate land requisition. However, local governments have multiple instruments to ease the pressure coming from rural land expropriation; the provision of welfare benefits is only one of them. The central government designed the UMURA program that combines rural welfare provision with a land quota rewarding system. In response, local governments, who desperately need land quotas, are eager to apply for the UMURA experimental status and become more willing to provide rural social welfare benefits. However, the provision of social welfare benefits is selective. First, such provision is not universal, but biased toward land-losing villagers; second, local officials provide land-losing villagers with social welfare benefits that are less costly, typically in the form of pension insurance. In developing these arguments, this study highlights three factors in explaining the land for welfare program in China: historical legacies from the communist 
system, the strategic interaction between the central and local governments, and selective provision of welfare benefits.

This study discusses three sets of actors involved in the land for welfare program the central government, local governments, and rural residents. The actual implementation of social welfare provision highlights complex strategic interaction between actors, particularly the central and local governments. The central government fears a potential threat to regime stability resulted from an increasingly impoverished rural population and the widening urban-rural gap; therefore, it prefers to improve rural welfare provision. Yet, relying on top-down pressure alone is hardly possible to guarantee successful preference fulfillment, particularly in China where policy implementation is highly decentralized. Instead, the central government formulated an incentive compatible program (i.e., the UMURA) that bundles social welfare provision with land to induce local governments to work in a way commensurate with the preference of the center. Following this logic, local welfare provision is not developed out of the local governments' benign intention, but their strategic reaction to the center's UMURA program. Local governments are clearly the beneficiaries in implementing the program, for they gain land and subsequent revenue.

The impact of the land for welfare program on farmers is somewhat mixed. Compared with the one-time cash payments, social welfare program provides an alternative land-taking compensation form that addresses the long-term livelihoods of the affected farmers. But not every land-losing villager has access to the welfare program. Indeed, inadequate compensation, forced eviction, and land-related corruption prevail in China, causing numerous rural protests against land expropriation (e.g., Guo 2001; Cai 2003; Tao et al. 2010; Liu, Fang and Li 2014). Even for those who are provided with welfare benefits, their land's insurance function is only partially compensated: while pension benefits are provided, unemployment insurance is not. Moreover, the price they have to pay in order to 
receive the welfare benefits is not trivial: they have to give up their land, possibly the most precious asset they have. In general, rural households are discriminated against during China's rapid urbanization. By institutional design, farmers are excluded from land conveyance, the very process of which allows governments to reap windfall revenue, primarily in the form of land transfer fees. The unfair treatment to rural households has inspired an informal and illegal land market to grow rapidly in China (Lin and Ho 2005; Su, Tao and Wang 2013). The land shareholding cooperatives (tudi gufenzhi) - individual rural households give up their land, which is consolidated into rural collectives, and receive yearly dividends in return - were created by some villages in Guangdong and have spread to other provinces (e.g., Fujian, Hunan, Jiangsu, and Zhejiang) with more or less variation (Cai 2003; Su, Tao and Wang 2013; Ministry of Land and Resources 2003). The so-called small-property houses prevail where houses are built on collectively-owned rural land and the buyers who purchased such houses generally do not have complete property rights to their houses. Despite being technically illegal, small-property houses remain attractive to many low-income people because they are significantly cheaper than the ones built on state-owned land in the housing market. The central government has been aware of the unfair treatment to affected rural households as a result of distorted land market and encouraged some localities to experiment with building a common land market, regardless urban or rural land ownership in 2013 (CCP Central Committee and the State Council, 2013, Article 11).

Thanks to decentralized policymaking, local response to land-taking compensation has progressed differently and at different paces across China. While this article aims to explain systematic variation in the relationship between land expropriation and rural welfare provision, it cannot include every scenario observed in the real world. Some local governments started providing land-losing farmers with pension insurance before the official announcement of the UMURA program. This observation precisely reflects the policy experimentation mechanism in policymaking in China, by which local innovations are 
implemented within a small scale first, and national policies, regulations, and laws are drafted later. During this process the central government has the authority to scale up and generalize local innovations as it see appropriate (Heilmann 2008a, b). This process can take time. While the land for welfare program has been implemented across many provinces for more than a decade, it still has not been incorporated into state laws on land-taking compensation. Some studies observe that private enterprises are an important actor in implementing the UMURA program in some localities (Long et al. 2012). Arguably, if local governments are able to transfer their cost of welfare provision to private enterprises (or any other actor for that matter), they are anticipated to be more willing to provide affected rural households with more generous welfare benefits. While the data do not allow me to systematically test this hypothesis, the participation of non-state players in state-designed land programs opens up an area for further research.

Due to limited data availability, the social welfare benefits examined in this article are limited to pensions and unemployment insurance. But the logic of land for welfare applies to other welfare benefits, such as guaranteed minimum living benefits, land's another insurance function in rural China. Rural health care provision may not be closely linked with land requisition. The central government has taken a more aggressive approach in establishing a rural health care system, which, like other reforms, started from a few experimental sites and was intended to be gradually expanded nationwide (CCP Central Committee and the State Council, 2005, Article 20). The logic of land for welfare may also explain the provision of rural public goods. Local governments build rural communities with better facilities (such as access to roads, flush toilets, and sewage treatment), making villagers more willing to move to these new communities. Once they move, their individual housing plots - a source of rural construction land - become available for local governments to convert into urban construction land.

Empirically, providing affected rural residents with social insurance has serious 
consequences. Land-losing villagers who receive only one-time cash compensation can easily exhaust their cash payments and become more impoverished than the time before their land was expropriated. As the size of this group grows, the urban-rural gap does not narrow; rather, it widens. To mitigate the profound urban-rural gap, the central government has recently taken action to encourage rural pension provision. In August 2009, former Premier Wen Jiabao promised that the central government would provide full financial support for rural pension provision in the central and western regions and will subsidize 50 percent of local government spending on rural pension provision in the east.

The central government's goal is to have rural pensions provided nationwide by 2020 (The State Council 2009). The central government's action provides local governments with a financial incentive, but only time will tell whether this financial incentive will be sufficient to motivate local officials to expand rural pension provision from land-losing farmers in experimental sites to the entire country.

\section{Acknowledgements}

The author would like to thank Scott Gehlbach, Melanie Manion, David Weimer, Edward Friedman, Yoi Herrera, Rikhil Bhavnani, and the participants of the New Faces in China Studies Conference at Duke University for helpful comments on an earlier draft. She is grateful to the anonymous referees for helpful comments. She also thanks Melanie Manion for sharing the China Survey data. Financial support from the National Science Foundation, the Chiang Ching-kuo Foundation, the Institute for Humane Studies, and the University of Wisconsin-Madison is gratefully acknowledged. 


\section{References}

Cai, Yongshun. 2003. "Collective Ownership or Cadres' Ownership? The Non-agricultural Use of Farmland in China." The China Quarterly (175):662-680.

Chan, Kam Wing and Will Buckingham. 2008. "Is China Abolishing the Hukou System." The China Quarterly (195):582-606.

Cheng, Tiejun and Mark Selden. 1994. "The Origins and Social Consequences of China's Hukou System." The China Quarterly (139):644-668.

Chinese Communist Party Central Committee. 2013. "guanyu quanmian shenhua gaige ruogan zhongda wenti de jueding." (Decision on major issues on deepening reforms), November 12, 2013.

Chinese Communist Party Central Committee and the State Council. 2003. "Guanyu cujin nongmin zengjia shouru ruogan zhengce de yijian." (Suggestions on Improving Rural Household Income). December 31, 2003.

Chinese Communist Party Central Committee and the State Council. 2005. "Guanyu tuijin shehui zhuyi xin nongcun jianshe de ruogan yijian." (Suggestions on Building New Socialist Countryside). December 31, 2005.

Chinese Communist Party Central Committee and the State Council. 2007. "Guanyu qieshi jiaqiang nongye jichu sheshi jinyibu cujin nongye fazhan nongmin zengshou de ruogan yijian." (Suggestions on Improving Agricultural Infrastructure, Agricultural Development, and Rural Household Income). December 31, 2007.

Chinese Communist Party Central Committee and the State Council. 2009. "Guanyu jiada tongchou chengxiang fazhan lidu jinyibu hangshi nongye nongcun fazhan jichu de ruogan yijian." (Suggestions on Making Progress on Unified Management of Urban and Rural Areas and Consolidating Agricultural Development). December 31, 2009.

Chongqing Daily. 2010. "Chongqing dipiao jiaoyi jiage zaichuang xingao." (Chongqing Land Ticket Created a Highest Transaction). http://www.cq.xinhuanet.com/2010-05/05/content_19695793.htm, May 5, 2010.

Chongqing Development and Reform Commission. 2010. "Chongqing shiyanqu." (Chongqing Experiment), 2010. On file with author.

Economy, Elizabeth. 2012. "China's land grab epidemic is causing more Wukan-style protests." The Atlantic .

Edin, Maria. 2003. "State Capacity and Local Agent Control in China: CCP Cadre Management from a Township Perspective." The China Quarterly (173):35-52.

Fan, C Cindy. 2006. "China's eleventh five-year plan (2006-2010): from "getting rich first" to "common prosperity"." Eurasian Geography and Economics 47(6):708-723.

Foshan Bureau of Land and Resources. 2008. "Report on Reforming Land Exporpriation in Foshan." October 25, 2008. On file with author. 
Guo, Gang. 2009. "China's Local Political Budget Cycles." American Journal of Political Science 53(3):621-632.

Guo, Xiaolin. 2001. "Land Expropriation and Rural Conflicts in China." The China Quarterly (166):422-439.

Heilmann, Sebastian. 2007. "Policy Experimentation in China's Economic Rise." Studies in Comparative International Development 43(1):1-26.

Heilmann, Sebastian. 2008a. "From Local Experiments to National Policy: The Origins of China's Distinctive Policy process." The China Journal (59):1-30.

Heilmann, Sebastian. 2008b. "Policy Experimentation in China's Economic Rise." Studies in Comparative International Development 43(1):1-26.

Huber, Evelyne, Thomas Mustillo and John D. Stephens. 2008. "Politics and Social Spending in Latin America." Journal of Politics 70(2):420-436.

Johnson, Ian. 2013. "China's Great Uprooting: Moving 250 Million into Cities." New York Times.

Katzenstein, Peter J. 1985. Small States in World Markets : Industrial Policy in Europe. Ithaca, New York: Cornell University Press.

Knight, John and Lina Song. 1999. The Rural-Urban Divide: Economic Disparities and Interactions in China. New York, New York: Oxford University Press.

Kung, James Kai-sing. 1995. "Equal Entitlement Versus Tenure Security Under a Regime of Collective Property Rights: Peasants' Preferences for Institutions in Post-Reform China." Journal of Comparative Economics 21(1):82-111.

Kung, James Kai-sing. 2000. "Common Property Rights and Land Reallocations in Rural China: Evidence from a Village Survey." World Development 28(4):701-19.

Landry, Pierre F. 2003. "The Political Management of Mayors in Post-Deng China." The Copenhagen Journal of Asian Studies 17:31-58.

Landry, Pierre F. 2008. Decentralized Authoritarianism in China: The Communist Party's Control of Local Elites in the Post-Mao Era. Cambridge, Massachusetts: Cambridge University Press.

Li, Hongbin and Li-An Zhou. 2005. "Political Turnover and Economic Performance: The Incentive Role of Personnel Control in China." Journal of Public Economics 89:1743-1762.

Lin, George C. S. 2009. Developing China: Land, Politics and Social Conditions. New York: Routledge.

Lin, George C. S and Samuel P. S Ho. 2003. "China's Land Resources and Land-Use Change: Insights from the 1996 Land Survey." Land Use Policy 20(2):87-107.

Lin, George C.S. and Samuel P. S. Ho. 2005. "The State, Land System, and Land Development Processes in Contemporary China." Annuals of the Association of American Geographers 92(2):411-436. 
Lin, Justin Yifu. 1992. "Rural Reforms and Agricultural Growth in China." American Economic Review 82(1):34-51.

Liu, Yansui, Fang Fang and Yuheng Li. 2014. "Key Issues of Land Use in China and Implications for Policy Making." Land Use Policy (40):6-12.

Long, Hualou, Yurui Li, Yansui Liu, Michael Woods and Jian Zou. 2012. "Accelerated Restructuring in Rural China Fueled by 'Increasing vs. Decreasing Balance' Land-Use Policy for Dealing with Hollowed Villages." Land Use Policy (29):11-22.

Lorentzen, Peter, Pierre Landry and John Yasuda. 2014. "Undermining Authoritarian Innovation: the Power of China's Industrial Giants." The Journal of Politics 76(1):182-194.

Ministry of Finance. 2009. China Fiscal Yearbook. Beijing: China Finance Press.

Ministry of Land and Resources. 2003. "Research Report on Reforming the Land Expropriation System." Land Resources Newsletter (11):48-55.

Ministry of Land and Resources. 2004. "Research Report on the Situation of Land Taking Compensation Arrears Repayment." Land Resources Newsletter (1):27-28.

Ministry of Land and Resources. 2007a. "Guanyu jinyibu guifan chengxiang jianshe yongdi zengjian guagou shidian gongzuo de tongzhi." (Notification on further Regulating Experimentation of Linking the Contraction of Rural Construction Land with the Expansion of Urban Construction Land), July 13, 2007.

Ministry of Land and Resources. 2007b. "guanyu jinyibu guifan chengxiang jianshe yongdi zengjian guagou shidian gongzuo de tongzhi." (Notification on further regulating experimentation of linking the contraction of rural construction land with the expansion of urban construction land), July 13, 2007.

Ministry of Land and Resources. 2008. "Chengxiang jianshe yongdi zengjia guagou ganli banfa." (Administrative Measures on Linking the Contraction of Rural Construction Land with the Expansion of Urban Construction Land), June 27, 2008.

Ministry of Land and Resources. 2009. China Land and Resources Statistical Yearbook. Beijing: China Geology Press.

Montinola, Gabriella, Yingyi Qian and Barry R. Weingast. 1995. "Federalism, Chinese Style: The Political Basis for Economic Success in China." World Politics 48(1):50-81.

Nanxun Government. 2009. "Nanxunqu xinongcun shiyan shifanqu jianshe gongzuo jianbao." (Working Brief on Establishing New Villages in Nanxun), June 9, 2009.On file with author.

National Bureau of Statistics of China. 2012. China Statistical Yearbook. Beijing: China Statistics Press.

National People's Congress. 2004. "Land Administration Law." August 28, 2004.

National People's Congress. 2007. "Property Rights Law.” March 16,2007. 
Oi, Jean C. and Shukai Zhao. 2007. Fiscal Crisis in China's Township: Causes and Consequences. In Grassroots Political Reform in Contemporary China, ed. Elizabeth J. Perry and Merle Goldman. Cambridge, Massachusetts: Harvard University Press pp. 75-96.

Party committee of Jiulongpo District, Chongqing. 2007. "Jiulongpoqu chengxiang tongchou fazhan cujin nongmin bian shimin shixing banfa." (Jiulongpo Interim Regulations on Urban-Rural Unified Management and Transformation of Rural Residents to Urban Residents). On file with author.

Peimin, Lou. 2007. "A Case Study on the Settlement of Rural Women Affected by Land Requisitioning in China." Journal of Contemporary China 16(50):133-148.

Perkins, Dwight H. 2009. China's Land System:Past, Present, and Future. In Property Rights and Land Politics, ed. Gregory K. Ingram and Yu-Hung Hong. Cambridge: Lincoln Institute of Land Policy pp. 70-92.

Rodrik, Dani. 1998. "Why Do More Open Economies Have Bigger Governments?" The Journal of Political Economy 106(5):997-1032.

Selden, Mark and Laiyin You. 1997. "The Reform of Social Welfare in China." World Development 25(10):1657-1668.

Sheng, Yumin. 2010. Economic Openness and Territorial Politics in China. Cambridge, Massachusetts: Cambridge University Press.

Shih, Victor, Christopher Adolph and Mingxing Liu. 2012. "Getting Ahead in the Communist Party: Explaining the Advancement of Central Committee Members in China." American Political Science Review 106(1):166-187.

Smart, Aland and Josephine Smart. 2001. "Local citizenship: Welfare Reform Urban/Rural Status, and Exclusion in China." Environment and Planning A 33:1853-1869.

Su, Fubing, Ran Tao and Hui Wang. 2013. "State Fragmentation and Rights Contestation: Rural Land Development Rights in China." China \& World Economy 21(4):136-155.

Tao, Ran, Fubing Su, Mingxing Liu and Guangzhong Cao. 2010. "Land Leasing and Local Public Finance in China's Regional Development: Evidence from Prefecture-level Cities." Urban Studies 47(10):2217-2236.

The State Council. 1990. "chengzhen guoyou tudi shiyongquan churang he zhuanrang zanxing tiaoli." (Interim Regulations on Transfers of Urban State-owned Land Use Rights), May 19, 1990.

The State Council. 1998. "tudi guanlifa shishi tiaoli." (Regulations on the Implementation of the Land Administration Law), December 27, 1998.

The State Council. 2009. "Guowuyuan fabu kaizhan xinxing nongcun shehui yanglao baoxian shidian zhidao yijian." (Guidance on Experimentation with New Rural Pension System) September 4, 2009. 
Tsui, Kai-yuen and Youqiang Wang. 2004. "Between Separate Stoves and A Single Menu: Fiscal Decentralization in China." The China Quarterly (177):71-90.

Unger, Jonathan and Anita Chan. 1999. "Inheritors of the Boom: Private Enterprise and the Role of Local Government in a Rural South China Township." The China Journal (42):45-74.

Wang, Fei-Ling. 2005. Organizing Through Division and Exclusion. Stanford, California: Stanford University Press.

Wang, Hui, Ran Tao and Juer Tong. 2009. "Trading Land Development Rights under a Planned Land Use System: the "Zhejiang Model"." China $\&$ World Economy 17(1):66-82.

Wang, Hui, Ran Tao, Lanlan Wang and Fubing Su. 2010. "Farmland Preservation and Land Development Rights Trading in Zhejiang, China." Habitat International $34(4): 454-463$.

Whiting, Susan H. 2000. Power and Wealth in Rural China: The Political Economy of Institutional Change. Cambridge, Massachusetts: Cambridge University Press.

Whiting, Susan H. 2004. The Cadre Evaluation System at the Grassroots. In Holding China Together: Diversity and National Integration in the Post-Deng Era, ed. Barry J. Naughton and Dali L. Yang. Cambridge, Massachusetts: Cambridge University Press.

Whiting, Susan H. 2011. Fiscal Reform and Land Public Finance: Zouping County in National Context. In China's Local Public Finance in Transition, ed. Joyce Yanyun Man and Yu-Hung Hong. Cambridge, Massachusetts: Lincoln Institute of Land Policy pp. 125-144.

Whyte, Martin King, ed. 2010. One Country, Two Societies. Cambridge, Massachusetts: Harvard University Press.

Wong, Christine. 2009. "Rebuilding Government for the 21st Century: Can China Incrementally Reform the Public Sector?" The China Quarterly (200):929-952.

World Bank. 2002. China National Development and Subnational Finance. Washington, DC: World Bank.

Xiaoshan Social Security Management Office. 2012. "Xiaoshanqu zhengdi nongzhuanfei yaolao baoxian xinzhengce." (Xiaoshan Pension Policy for Land-losing villagers). http://www.Idbz.xs.zj.cn/0303/2983.htm, May 5, 2010.

Xu, Chenggang. 2011. "The Fundamental Institutions of China's Reforms and Development." Journal of Economic Literature 49(4):1076-1151.

Yao, Yang. 2004. Land, Institutions and Agricultural Development. Beijing: Beijing University Press.

Yep, Ray. 2013. "Containing Land Grabs: A Misguided Response to Rural Conflicts over Land." Journal of Contemporary China 22(80):273-291. 
Yew, Chiew Ping. 2012. "Pseudo-Urbanization? Competitive Government Behavior and Urban Sprawl in China." Journal of Contemporary China 21(74):281-298.

Zhang, Weiwen, Wen Wang, Xuewen Li and Fangzhi Ye. 2014. "Economic Development and Farmland Protection: An assessment of Rewarded Land Conversion Quotas Trading in Zhejiang, China." Land Use Policy 38:467-476.

Zhao, Li, Hongbao Hu and Kaihong Yu. 2008. "Empirical Analysis of Implementing Land for Security: A Case Study of Land-Losing Peasants from Xiaoshan." Township Economy (xianzhen jingji) 4:20-24. 